\title{
Особливості використання психотерапевтом мовленнєвих структрур НЛП
}

\begin{abstract}
Анотація. У статті розглядаються мовленнєві феномени НЛП. За допомогою мовленнєвих феноменів психотерапевт моделює ситуацію та здійснює вплив на підсвідомість клієнта, що дозволяє клієнту вийти за його власний досвід $i$ змоделювати ситуаџію. НЛП виходить із того, щзо функиіонування мислення людини значною мірою нагадує роботу комп'ютера, однак не в сенсі тривіальної комп'ютерної метафори, на якій виросла сучасна когнітивна психологія, а через те, ще мислення людини програмоване. Все питання в тому, щоб правильно сформувати програму, $і$ зробити ї доступною для свідомості і підсвідомості людини. Звідси поняття моделювання: терапевт намагається виявити найкращий засіб, за допомогою якого людина вирімує певну задачу, і намагається зробити иее доступним для иієї людини чи для іншої особи. Засіб верифікації моделі в результаті полягає не в міркуваннях про те, чи правильна модель, чи відповідає вона дійсності, а в тому, щзо модель успішно виконує свої функиії. Згідно НЛП, взагалі важко говорити про правильність чи відповідність реальності будь-якому досвіду. В найкращзому випадку можна говорити про те, щзо деякий досвід стосується сукупності загальноіснуючих уявлень про оточуючий світ. Використання мовленнєних феноменів НЛП у психотерапії дозволяє нам говорити про подальші дослідження в сфері практичної психології.
\end{abstract}

Ключові слова: нейронлінгвістичне програмування, мовленнєві структури, моделювання, мовлєнневі феномени, метафора, репрезентативні системи.

Актуальність. Сучасне суспільство потребує спеціалістів, а саме психологів, які володіють різними психотерапевтичними методами та техніками. Їх можуть застосовувати як психотерапевти у своїй роботі з клієнтами, що свідчить про їх високу професійну компетентність. А саме, техніки нейролінгвістичного програмування у наш час дуже широко використовують психологи з ближнього та далекого зарубіжжя, що дозволяє їм за допомогою мовленнєвих впливів на свідомість та підсвідомість клієнта отримати вирішення проблем клієнта, та також цей метод використовується як моделювання ситуацій, що дозволяє істотно поліпшити психологічний стан людини.

Нейролінгвістичне програмування (НЛП), напрям у теоретичній і практичній психології, який відрізняється від аналогічних психотерапевтичних методів психоаналізу, групової психотерапії, гештальттерапії орієнтуванням на ефективність поведінки терапевтичного втручання. Згідно з однією теорією, НЛП виникло як теоретичне узагальнення характерних особливостей практики відомих психотерапевтів, які нагадують невтаємниченому глядачу магію. Звідси виникла «Структура магії» - назва однієї з книг Р. Бендлера та Дж. Гріндера. 3 точки зору психології як науки, теоретична новизна НЛП містить в собі зміну фокусу уваги дослідника i, як наслідок, психотерапевта: замість девіацій психічного стану НЛП рекомендує основну увагу звертати навіть не на норму, якої не існує, а на зразки успішної поведінки людини в кризових ситуаціях [1, с. 101-103]. На думку засновників НЛП, важливою особливістю НЛП є зв'язок положень НЛП з мовою та знаннями особливостей функціонування мовної системи. Засновниками НЛП прийнято нами вважати Річарда Бендлера, Джона Гріндлера, Леслі Кемерон-Бендлер, Девіда Гордона і Майкла Спаркса.

НЛП як психотерапевтичний метод. Процес моделювання проходить декілька етапів. На першому етапі відбувається збір інформації про поточний стан клієнта і бажаний стан, фактично про саму сутність впливу. На наступних етапах суть бажаного стану послідовно уточнюється. 
На другому етапі встановлюється раппорт, це такі стосунки між комунікатором та клієнтом, за яких між ними існує максимальна взаємна довіра. Досягнення раппорту — важливе завдання НЛП. Раппорт досягається на свідомому чи несвідомому рівні, коли комунікатор приєднується до репрезентативних систем клієнта, відображаючи їх у своїй вербальній чи невербальній поведінці. Під репрезентативною системою в НЛП розуміють засіб уявлення та осмислення свого досвіду взаємодії 3 оточуючим світом. Це може бути візуальна репрезентативна система (досвід уявляється як послідовність візуальних образів), аудіальна репрезентативна система (досвід осмислюється як послідовність звуків різного типу), кінестетична репрезентативна система (досвід уявляється як тактильні відчуття), нюхо-смакова репрезентативна система (досвід сприймається людиною як послідовність запахів та смакових відчуттів). Відображуючи реакції клієнта в кожній із цих систем, підлаштовуючись під них, комунікатор може досягнути 3 ним раппорту. Відображення може бути вербальним (комунікатор повторює ті чи інші особливості вербальної поведінки клієнта) та невербальним. В останньому випадку комунікатор підлаштовується під важливі елементи невербальної поведінки, вказуючи на провідну репрезентативну систему - під темп, подих, жести, рух очей і т.п. Досягнення раппорту може бути достатньо тривалою процедурою, але в деяких випадках він досягається дуже швидко - все залежить від майстерності комунікатора та тяжкості даного випадку.

Розглянемо деякі види підлаштування:

- підлаштування по позі та жестам;

- по диханню та ритму;

- по інтонації голосу;

- по тону, висоті голосу;

- по окоруховим параметрам;

- по репрезентативним системам.

Після досягнення раппорту комунікатор повинен встановити, чого бажає клієнт. Іншими словами, яким повинен бути сформований результат моделювання, що не повинен суперечити тим чи іншим сто- ронам особистості клієнта та не може шкодити його найближчому навколишньому середовищі.

Досліджуючи репрезентативні системи людини для наступного досягнення раппорту, комунікатор, окрім невербальних аспектів поведінки клієнта, повинен особливу увагу звертати на мову. Для цього в НЛП розроблена так звана мета-модель мови. В основі мета-моделі лежить припущення, що мова - як і найбільші форми соціального досвіду - виступає як фільтр, який переструктуровує досвід або у всякому разі хоча $б$ структурує його. Мета-модель звертає увагу комунікатора на ті засоби мовної системи, які частіше всього переструктуровують сприйняття. Мета-модель представляє собою деякий конспект результатів із граматичної теорії, теорії мовного впливу та прагмалінгвістики, вибудований під цілі психотерапевтичної практики; певний вплив на формування НЛП виявили також ідеї «загальної семантики». Експліцитне виявлення, що їх вносить мова переструктурувань, складає значну частину психотерапевтичної процедури. Іншими словами, мета-модель мови - це зовсім не модель мови та її окремих підсистем, а модель поведінки комунікатора до природної мови, що використовують в процесі спілкування 3 клієнтом [5].

Лінгвістичний аспект НЛП. Інтерпретацією та використанням знань про мову в НЛП займаються непрофесійні лінгвісти. Тому опис лінгвістичного упорядкування НЛП в рамках власної лінгвістичної парадигми потребує певної корекції тих лінгвістичних категорій, апеляція до яких використовується в оригінальних працях представників цього напрямку.

Основний лінгвістичний постулат НЛП можливо сформулювати як гіпотезу про неадекватність мови як засобу відображення дійсності та досвіду людини.

Слова - тільки штучні ярлики для досвіду, а сама мова становить собою фільтр, який дозволяє когнітивній системі відсікати все зайве $з$ досвіду для того, щоб система не перевантажувалась та адекватно функціонувала. Однак ця корисна функція 
призводить до того, що свідомість людини ігнорує важливі частини цього досвіду, а це призводить до формування істотно збіднілого списку альтернатив при вирішенні проблемних ситуацій. Мета-модель мови дозволяє виявити найбільш типові випадки переструктурування та виправити їх, примноживши позитивний досвід людини.

Другий постулат ніби течія в протилежному напрямку від реальності - він визначає характер зв'язку між мовою та психікою. Це постулат про ізоморфність мови, з одного боку, і психічних або розумових процесів - 3 іншого. Згідно цього постулату, мовленнєві форми регулярно відображають особливості мислення та психічного стану людини. Звернувши увагу на особливості мовлення клієнта, комунікатор в змозі виявити його провідну репрезентативну систему, а також встановити галузі припущення важливого досвіду. Іншими словами, мова і мовлення розглядаються як важливі джерела інформації про психічний стан людини. Правильно і зворотне: хоча переважне використання якогось одного мовленнєвого засобу наврядчи призведе до хвороби, однак комплекс відповідних мовленнєвих висловів дозволяє викликати потрібний психічний стан. Саме тому за допомогою мови можливий терапевтичний вплив.

Важливим наслідком постулату про іконічність є принцип психологічного розмежування поверхневої та глибинної структур висловлювання. Інтерпретуючи це протиставлення в стилі трансформаціоналізму опоненти НЛП приписують поверхневій структурі функцію відображення свідомості, а глибинній — підсвідомості. Глибинна структура має вміст актантів тих змінних, які належить експліцитно заповнювати, щоб виявити дійсну, реальну проблему клієнта і створити уявлення про «добре сформований результат» моделювання.

Розглянемо мовленнєві структури, які використовують на різних етапах нейролінгвістичного програмування, в різних техніках НЛП. Фактично ці мовленнєві феномени і формують мета-модель мови, яка лежить в основі НЛП.

Мемафори. Метафора - один із найулюбленіших інструментів НЛП. Відома книга Д. Гордона не випадково має назву «Терапевтичні метафори». Втім, інтерпретується ця категорія в НЛП по-різному. Найбільш близько у лінгвістичному розумінні метафора використовується в мета-моделі мови. На цьому етапі комунікатор повинен визначити, яка репрезентативна система, тобто засіб осмислення досвіду, найбільш розвинений у клієнта i, отже, найчастіше ним використовується. Якщо звернутися до інструментарію когнітивної лінгвістики, можна сказати, що репрезентативна система - це структура знань, фрейми, в термінах яких людина осмислює свій досвід і структурує його, надає йому змісту. На поверхневому рівні мовленнєвої поведінки ці фрейми можуть бути представлені метафорами, точніше - метафоричними моделями.

У НЛП виділяють чотири типи репрезентативних систем: 1) візуальна репрезентативна система, яка дозволяє структурувати та осмислювати досвід як послідовність візуальних зображень, картинок, що виникають у свідомості людини; 2) аудіальна репрезентативна система, в рамках якої досвід структурується як послідовність звуків різного типу, музики, шумів і т.п.; 3) кінестетична репрезентативна система, яка дозволяє осмислювати досвід як зміну відчуттів тіла; 4) репрезентативна система нюху та смаку, яка відтворює досвід як послідовність запахів та смакових відчуттів. Одна 3 репрезентативних систем для людини є первинною, головною. Цю систему i повинен виявити комунікатор на етапі збору інформації про клієнта. В цьому випадку аналізується як вербальна, так і невербальна поведінка клієнта. Невербальна складова — це дослідження за допомогою ключів доступу, якими виявляються рухи очей. Для кожного типу репрезентативної системи вони дійсно специфічні. При дослідженні вербальної поведінки для виявлення репрезентативної системи велике значення має аналіз метафор, які викорис- 
товує клієнт. В НЛП ці вирази часто називають «процесуальними словами». Фактично мова йде про метафоричні моделі, закладені в переносних значеннях слів та в оригінальній метафориці клієнта. Наприклад, візуальна репрезентативна система встановлюється за такими виразами, як: «Я бачу, що він мене не розуміє»; «Я неясно розумію, що тут щось не так»; «Мені здається, що всі проти мене»; «Ця картина так і стоїть перед мною».

Аудіальна репрезентативна система має прояв у метафоричних моделях, джерелом яких $€$ звук, а також розгорнуті порівняння 3 таким же джерелом. Наприклад: «Ця проста, але зрозуміла думка просто приголомшила мене»; «Спогади того літа залишились хороводом звуків над поверхнею річки вранці».

Кінестетична репрезентативна система встановлюється за значеннями слів, в основі яких лежать метафори з джерелом - галуззю відчуттів: «Я відчуваю, що ви маєте рацію»; «Я натрапив в своїх спогадах щось потрібне, але не можу це вхопити»; «Мама була завжди стримана зі мною та не помічала, що я для неї робила». Репрезентативна система нюху та смаку виявляється у висловах наприклад: «Моє дитинство завжди викликає в мене гіркі спогади»; «Я спробую зосередитись, але не впевнений, що мені це зараз вдасться» [3, с. 234-237].

Виявлення первинної репрезентативної системи дозволяє як встановити раппорт 3 клієнтом, підлаштовуючись у вербальних реакціях під його первинну репрезентативну систему, так і розширити простір вибору клієнта, перевести осмислення досвіду в інші типи репрезентативних систем.

\section{Вправа «Знайомство розвідника».}

Мета: навчитись перед тим, як починати розмовляти - дослідити співбесідника та подумати, як говорити, а що не потрібно говорити.

Розмовляючи 3 співбесідником намагайтеся виявити його провідну репрезентативну систему, аудіальну, візуальну або кінестетичну, шляхом найбільш частого вживання висловів у мові притаманного тій чи іншій репрезентативній системі. Піс- ля виявлення ведучої репрезентивної системи намагайтеся підлаштуватися під його провідну репрезентативну систему для досягнення рапорту.

Поверхнева та глибинна структура. Одна 3 основних ідей трансформаційної моделі мови полягає в тому, що одна і та ж глибинна структура може реалізовуватися різними поверхневими структурами, при цьому глибинне уявлення базова структура — виявляється біднішою і простішою, ніж поверхнева. Таке варіювання представників НЛП не дуже цікавить. Фактично для них важлива не трансформаційна граматика в дусі Н. Хомського, а породжуюча семантика, що працює не стільки з синтаксисом, скільки з семантикою вимови. 3 точки зору НЛП, на глибинному рівні завжди будується повне, достатньо багате уявлення проблемної ситуації, але на поверхневому рівні воно у ряді альтернативних виборів, в результаті проведення різних трансформацій збіднюється. Наприклад, речення «Джон купив автомобіль» у глибинній структурі вміщує інформацію про те, в кого був придбаний автомобіль, за яку суму та коли. На глибинному рівні завжди наявна модель управління дієсловом 3 обов'язковими та факультативними валентностями, які більш докладно описують відповідну ситуацію. Збіднення, редукція поверхневої форми відбувається, як правило, несвідомо. В процесі терапевтичного впливу комунікатор повинен відновити на поверхневому рівні всі важливі глибинні елементи — припущення валентності та перш за все заповнюючи їхні актанти.

3 цієї точки зору, для НЛП значний інтерес представляють деякі трансформації, які регулярно «згортають» більш багатий зміст. До них відносяться, наприклад, трансформації припущення в діалогах типу: Клієнт: «Ну, я, взагалі, не впевнений». Терапевт: «Не впевнений у чому?» Клієнт: «Що мені варто говорить про це?» Терапевт: «Про що про це?» В першій репліці клієнта елімінінована вся складова, що реалізує обов'язкову валентність дієслова, а в другій - синтаксична складова $\epsilon$, але вона змінена на анафоричний займенник, 
однак анафора не розкрита. Ці випадки описуються в НЛП як вислови з відсутніми референтними індексами. Припускається, що в глибинній структурі референтні індекси завжди $\epsilon$, і терапевт повинен в процесі опитування клієнта експлікувати ці індекси, відновивши опущені антецеденти i склад. Треба також мати на увазі, що референтна структура розуміється в НЛП дуже розширено і включає комунікативні та когнітивні контексти вимови висловлювання, почуття людини відносно обговорюваних проблем і уявлення про те, як інші учасники комунікації сприймають подію.

Номіналізація. Аналогічне явище згортання змісту спостерігається при номіналізації. Як відомо, конструкції типу «Відмова від погодження приведе до неуспіху переговорів» приховують в глибинній структурі пропозиційні форми, наприклад, «дехто відмовився від погодження». Номіналізація — в термінології НЛП — збіднює досвід клієнта, оскільки не тільки переводить в імпліцитну форму деякі важливі аспекти ситуації, але й представляє деякі контрольовані процеси в формі неконтрольованих, що вже відбулися подій. В цьому випадку належить звернути увагу клієнта на процесуальний характер ситуації, на іiі контрольованість, а також на існування валентностей у дієслова «визнавати» або виразу «знаходити визнання» за допомогою запитань типу «У кого ви не знаходити визнання?» або «Чи можете ви собі уявити, що ви здобули визнання?»

Модальні оператори. Типовий мовний прояв збіднення свого досвіду i, як наслідок, звуження простору вибору - використання конструкцій 3 модальними словами, наприклад, «необхідно», «потрібно», «я повинен», «мені потрібно робити». Мета-модель мови в НЛП приписує цим конструкціям глибинну структуру. Психотерапевту необхідно примусити клієнта вийти за межі його обмежувального досвіду, зосередивши увагу на альтернативі: «Що трапиться, якщо ви не будете робити?»; «Що б трапилося, якби ви відмовились?» Наприклад, на репліку клієнта «Неможливо кохати двох жінок одночасно» психоте- рапевт може відповісти «Що вам заважає робити це?» або «Що трапиться, якщо ви будете кохати двох жінок одночасно?», «Чому неможливо одночасно кохати двох жінок?» Осмислення альтернативи розширить свідомий досвід клієнта та буде сприяти вирішенню проблеми, яка виникла.

Вирази з квантом узагальнення. Викривлення досвіду, його неправильна інтерпретація може бути пов'язана не тільки 3 опущенням, елімінацією, але й 3 необміркованим «добудуванням», «збагаченням» уявлень про реальність. Типове джерело викривлення такого типу - неправомірна генералізація, узагальнення. В природній мові вираз «завжди» інтерпретується або в послабленому кванторному сенсі «звичайно, як правило, найчастіше» або в «сильному» логічному сенсі. Зрозуміло, що вирази з квантором узагальнення в слабкому сенсі завжди можна поставити під сумнів з точки зору власного логічного значення. Це дуже важливо для психотерапевтичної процедури, оскільки генералізовані вислови клієнта, як правило, відносяться до його негативного досвіду і представляють собою інтерпретацію його емоцій, вражень від дійсності, а не фактичне знання. Так, вислів: «Я ніколи не був в Парижі» цілком верифікований, оскільки відображає реальний досвід суб'єкта. Однак вислови клієнта: «Мене ніхто не розуміє» відображають катастрофічне сприйняття дійсності. Для зниження значимості негативного досвіду клієнта та фокусу уваги на позитивному досвіді психотерапевт ставить під сумнів вислів клієнта 3 точки зору логічного розуміння: «Ви дійсно впевнені, що вас ніхто не розуміє?», «Невже не було випадку, коли вас хто-небудь зрозумів?»

Каузальні зв'язки. Усвідомлення дійсності з необхідністю установлення між подіями причинно-наслідкових зв'язків. Оскільки, суть НЛП складається з переосмислення досвіду, установлення нових зв'язків між явищами та почуттями, когнітивними станами, робота 3 причинними конструкціями виявляється ефективним інструментом впливу на адресата. 
Комунікативна техніка обмірковування причинних зв'язків припускає, що психотерапевт звертає увагу на відсутність необхідних зв'язків між подіями, які ставляться в причинно-наслідкову залежність. Наприклад, вислів клієнта: «Моя дружина дратує мене своєю поведінкою» приховує каузальну залежність «Моя дружина робить щось, що мене дратує».

Тут необхідно з'ясувати, на підставі чого клієнт вирішив, що його дружина свідомо дратує його, чи можна пояснити поведінку жінки чимось ще, чи завжди поведінка дружини викликає у клієнта почуття дратівливості і т.д.

Аналогічна техніка використовується i для висловів з більш експліцитними причинними зв'язками: «Я хочу стати іншим, але мої батьки мені заважають»; «Мені потрібно було поїхати з дому, але моя дружина була хвора». У всіх випадках мета комунікатора заключається у тому, щоб поставити під сумнів існування необхідного зв'язку між причиною та наслідком. Це можна зробити, виявивши випадки, коли зв'язків не було (Чи завжди так трапляється?), звернувши увагу на те, що ситуація могла виникнути ненароком (Хіба ваша дружина спеціально хотіла роздратувати вас?), спробувавши перевернути причинний зв'язок (Як би ваша дружина не була хвора, ви б обов'язково поїхали?)

Схована перформативність. Для НЛП важливо, що будь-яке твердження людини має сенс тільки у рамках його власної моделі світу. Нерозуміння цього $є$ ще одним джерелом омани, обмежуючим полем вибору альтернатив при прийнятті рішень в проблемних ситуаціях. В цих випадках корисно експлікувати глибинний перформатив, який, згідно перформативному аналізу, показаний в глибинній структурі будь-якого мовленєвого акту. Наприклад, перетворення вислову: «Погано діставати інших своїми власними проблемами» у форму $з$ експліцитним перформативом «Я стверджую, що погано діставати інших своїми власними проблемами» відразу зменшує сферу застосування твердження, обмежуючи іï моделлю світу самого мов- ця. Фактично це еквівалентно зняттю неправомірної генералізації [2].

Мета-модель мови. Модель природної мови в НЛП, являє собою набір інструкцій, за допомогою яких комунікатор контролює процес спілкування, а також виявляє ті частини дискурсу, які вказують на особливості мислення клієнта (виявлення первинної репрезентативної системи) та обмежують його позитивний досвід. Представлені вище феномени і утворюють частини мета-моделі, яка спочатку використовується для збору інформації про клієнта, а потім для вербального впливу. Зазначимо, втім, що часто ці етапи не протиставлені за часом та відбуваються одночасно.

\section{Вправа «План модельного розмаху».}

1. Визначте проблему. «Що ви хочете змінити? В чому ви дисгармонійні? Чим ви незадоволені?»

2. Зберіть інформацію. Використайте схему Р. Бєндлера «виконання»: «Я повинен на день замінити вас. Щоб виконати завдання продемонструйте мені, що я повинен робити». Вам потрібно дізнатися, коли це робити (стимул) та як (процес).

3. Перевірте стимул. Зробіть перевірку, зберіть більше інформації.

4. Розробить бажане Я-уявлення та перевірте, яким ви себе бачите та що ви робите, що говорите.

Значимість практики НЛП для теорії мови. Лінгвістичні постулати НЛП з упевненістю указують на існування ізоморфізму між мовленнєвими феноменами - такими як метафора, глибинна та поверхнева структура і процесами мислення. В теоретичному мовознавстві неодноразово виникали гіпотези про існування такого зв'язку, однак практичний доказ був неможливий. Досвід успішного використання принципів та дискусійних стратегій НЛП виявляється в цьому сенсі дуже важливим. Представляє також значний інтерес гіпотеза про психічну значимість практично кожного варіювання мовленнєвих форм, а в крайньому випадку на лексичному рівні. Зокрема, неусвідомлене варіювання метафоричних моделей представляє собою важливе дже- 
рело інформації про засоби осмислення світу людиною.

\section{Вправа «Формула поведінкової зміни» (Р. Дилтс)}

Ця вправа дає можливість швидко подолати найчисленніші переживання, що $є$ наслідком різних психологічних травм.

Етап перший. Підготовка. Оберіть три неприємні переживання з вашого минулого.

Етап другий. Сортування спогадів. Попросіть своє підсвідоме виокремити ваші минулі приємні спогади від неприємних.

Етап третій. Перекодування ваших минулих неприємних переживань.

Зробіть свої минулі неприємні переживання більш маленькими, менш яскравими, менш віддаленими.

Етап четвертий. Воз'єднання зі своїми приємними минулими переживаннями.

Спробуйте своє підсвідоме перекодувати всі подібні переживання, зробивши їх яскравими та більш великими. Намагай- тесь не спостерігати за ними зі сторони, а війдіть в них, щоб повністю відчути їх.

Етап п'ятий. Перенос знання в теперішній час, перенесіть даний спосіб сприйняття приємних та неприємних подій в теперішній час.

Етап шостий. Перекодування майбутнього. Перенесіть цей спосіб сприйняття приємний та неприємних подій в майбутнє [4].

\section{Висновки.}

Використання психотерапевтом мовленнєвих структур НЛП перш за все може засвідчити про його професійну компетентність, такі мовленнєві феномени можуть допомогти клієнту знайти вирішення своєї проблеми на глибинному рівні та переструктурувати його досвід, що є перевагою перед іншими психотерапевтичними техніками. Використання мовленнєвих феноменів НЛП у психотерапії дозволяє нам говорити про подальші дослідження в області практичної психології.

\section{Список використаних джерел:}

1. Бэндлер Р. Структура магии / Р. Бэндлер, Д. Гриндер. - СПб. : Питер, 1996. - С. 101103.

2. Бэйли Р. НЛП-консультирование / Р. Бэйли. - Москва : Просвещение, 2000. C. 345-346.

3. Гордон Д. Терапевтические метафоры / Д. Гордон. - СПб. : Питер, 1996. - С. 234-237.

4. Дилтс Р. Фокусы языка. Изменение убеждений с помощью НЛП / Р. Дилтс. - СПб. : Питер, 2000. - С. 267-272.

5. О'Коннор Дж. Введение в нейролингвистическое программирование / Дж. О'Коннор, Дж. Сеймор. - 2-е изд. - Челябинск : «Библиотека А. Миллера», 1998. — С. 48-49.

Аннотация. В статье расматриваються речевые феномены НЛП. С помощью речевых феноменов психотерапевт моделирует ситуацию и оказывает влияние на подсознание клиента, что позволяет клиенту выйти за его собственный опыт и смоделировать новую ситуацию.

НЛП исходит из того, что функиионирование мышления человека в значительной степени напоминает работу компьютера, однако не в смысле тривиальной компьютерной метафоры, на которой выросла современная когнитивная психология, а в том смысле, что мылиление человека программируемое. Весь вопрос в том, чтобы правильно сформировать программу и сделать ее доступной для сознания и подсознания человека. Отсюда понятие моделирования: терапевт пытается выявить лучшее средство, с помощью которого человек выполняет определенную задачу, и пытается сделать это доступным для этого человека или для другого лица. Средство верификачии модели в результате заключается не в рассуждениях о том, правильная модель или нет, соответствует ли она действительности или нет, а в том, что модель успешно выполняет свои функиии. Согласно НЛП, вообще трудно говорить о правильности или соответствие реальность каком-либо опыта. В лучшем случае можно говорить о том, что некоторый опыт относится к совокупности большей или менее общесущестующих представлений об окружающем мире.

Использование речевых феноменов НЛП в психотерапии позволяет нам говорить о дальнейших исследованиях в области практической психологии. 
Ключевые слова: нейролингвистическое программирование, речевые структуры, моделирование, речевые феномены, метафора, репрезентативные системы.

Annotation. The paper accepted for consideration speech phenomena NLP. With the help of speech therapist phenomena simulates the situation and influence the subconscious mind of the client, allowing the client to go beyond his own experience and simulate a new situation.

$N L P$ comes from the fact that the functioning of human thinking is largely reminiscent of the computer, but not in the sense trivial computer metaphor, which has grown modern cognitive psychology, but in the sense that human thinking programmable. The whole point is to properly shape the program and make it accessible to human consciousness and subconsciousness. Hence the notion of simulation: the therapist tries to bring out the best means by which a person performs a specific task, and trying to make it available to the person or to another person. Means of verification of the model as a result is not in the arguments about the right model or not, whether it is true or not, but the fact that the model is performing well. According to NLP, it's difficult to talk about the correctness or compliance with any real experience. At best, we can say that some experience relates to the totality of more or less common ideas about the world.

Using voice phenomena NLP in psychotherapy allows us to talk about further studies in the field of practical psychology.

Keywords: neuro-linguistic programming, speech structure, modeling, speech phenomena metaphor representational systems. 